\title{
PENGARUH EKUITAS MEREK, HARGA DAN KUALITAS PELAYANAN TERHADAP KEPUTUSAN PEMBELIAN PADA GERAI STARBUCKS DI BALI
}

\author{
Ni Putu Evi Agustini' \\ I Gst. A. Kt. Gd. Suasana² \\ Fakultas Ekonomi dan Bisnis Universitas Udayana, Bali, Indonesia \\ E-mail : eviagustini97@gmail.com
}

\begin{abstract}
Effect of Brand Equity, Price and Service Quality on Purchasing Decisions at Starbucks Outlets in Bali.The purpose of this study was to determine the effect of brand equity, price and service quality on purchasing decisions. The study was conducted on Starbucks consumers in Bali with a sample of 145 respondents using purposive sampling. Data collection using a questionnaire. The analysis technique used is multiple regression analysis. The analysis found that brand equity has a positive and significant effect on purchasing decisions, price has a positive and significant effect on purchasing decisions, and service quality has a positive and significant effect on purchasing decisions. Other results found that simultaneously brand equity, price and service quality variables also have a positive and significant effect on purchasing decisions. Based on the results of the study found, Starbucks has reached a good level of brand equity. Starbucks is expected to maintain the quality of service to consumers so as to increase sales.
\end{abstract}

Keywords: Brand Equity; Price; Service quality; Buying decision.

Abstrak: Pengaruh Ekuitas Merek, Harga Dan Kualitas Pelayanan Terhadap Keputusan Pembelian Pada Gerai Starbucks Di Bali. Tujuan penelitian ini adalah untuk mengetahui pengaruh ekuitas merek, harga dan kualitas pelayanan terhadap keputusan pembelian. Penelitian dilakukan pada konsumen Starbucks di Bali dengan sampel penelitian sebanyak 145 responden menggunakan metode purposive sampling. Pengumpulan data menggunakan kuesioner. Teknik analisis yang digunakan adalah analisis regresi berganda. Hasil analisis ditemukan bahwa ekuitas merek berpengaruh positif dan signifikan terhadap keputusan pembelian, harga berpengaruh positif dan signifikan terhadap keputusan pembelian, serta kualitas pelayanan berpengaruh positif dan signifikan terhadap keputusan pembelian. Hasil lain ditemukan bahwa secara simultan variabel ekuitas merek, harga dan kualitas pelayanan juga berpengaruh positif dan signifikan terhadap keputusan pembelian. Berdasarkan hasil penelitian ditemukan, Starbucks sudah mencapai tingkat ekuitas merek yang baik. Starbucks diharapkan dapat mempertahankan kualitas pelayanan terhadap konsumen sehingga dapat meningkatkan penjualan.

Kata kunci: Ekuitas Merek; Harga; Kualitas Pelayanan; Keputusan Pembelian. 


\section{PENDAHULUAN}

Keputusan pembelian adalah suatu proses pendekatan penyelesaian masalah yang terdiri dari pengenalan masalah, mencari informasi, beberapa penilaian alternatif, membuat keputusan membeli dan perilaku setelah membeli yang dilalui konsumen (Kotler \& Armstrong, 2012). Faktor-faktor yang mempengaruhi keputusan pembelian yang berhubungan dengan rangsangan pemasaran adalah produk (merek, rasa, kemasan, kualitas), promosi (periklanan, personal selling, publisitas dan promosi penjualan), distribusi (aksestabilitas) serta pelayanan dan harga (Kotler \& Keller, 2007).

Persaingan mengharuskan perusahaan menciptakan sesuatu yang mudah tertanam di benak konsumen dan salah satu aset yang dapat dipergunakan untuk mencapai keadaan tersebut adalah merek (Sigiro et al., 2016). Aristyani \& KertiYasa (2013)menyatakan bahwauntuk dapat bertahan pada pasar yang kompetitif diperlukan merek (brand) yang dapat menciptakan nilai tambah. Merek memiliki peranan yang sangat penting karena dapat mempersatukan harapan konsumen sesuai dengan yang dijanjikan (Chen \& Lynn 2013).
Merek merupakan nama, istilah, tanda, simbol, rancangan atau kombinasi dari suatu hal yang dimaksudkan untuk mengidentifikasi barang atau jasa dari seorang atau sekelompok penjual untuk membedakannya dari produk pesaing (Kotler \& Keller, 2007). Garlina (2014) menyatakan bahwa merek juga memiliki nilai yang tinggi, nilai prestasi yang baik, memiliki kekuatan dan ekuitas merek (brand equity) yang besar. Merek yang kuat sudah pasti dapat menguasai pasar karena kekuatan merek merupakan aset perusahaan yang paling bernilai yang dapat digunakan untuk memprediksi kelangsungan hidup perusahaan (Shabbir \& Jing, 2014).

Armandhani \& Sukaatmadja (2014) menyatakan, untuk mampu mengungguli para pesaing diperlukan brand equity yang kuat, karena semakin kuat brand equity suatu produk maka semakin kuat pula daya tarik dan nilai tambah produk tersebut di mata konsumen dan merek pesaing, yang selanjutnya dapat menggiring konsumen untuk melakukan pembelian serta mengantarkan perusahaan untuk memperoleh keuntungan. Omer (2014) menyatakan bahwa ekuitas merek juga mampu memberikan beberapa keunggulan seperti 
peluang dan komunikasi. Perusahaan yang ingin tetap bertahan dan melangkah lebih maju untuk memenangkan persaingan sangat perlu untuk mengetahui kondisi brand equity produknya melalui riset terhadap elemen brand equity.

Durianto (2011) menyatakan brand equity adalah aset yang memberikan nilai tersendiri dimata konsumen. Apabila brand equity tinggi, maka nilai tambah yang diperoleh konsumen dari produk tersebut akan semakin tinggi dari merek-merek pesaing. Brand equity mampu berperan sebagai identitas merek seperti logo, symbol, merek dagang dan slogan untuk dapat mengidentifikasi dan melihat bagaimana pengaruh produk terhadap konsumen. Brand equity terdiri dari 4 elemen yakni brand awareness, perceived quality, brand association dan brand loyalty (Durianto, 2011).

Kesadaran merek (brand awareness) merupakan kemampuan konsumen untuk mengenali dan mengingat kembali suatu merek merupakan bagian dari kategori produk tertentu (Aaker, 2013). Kesadaran merek mengacu pada apakah konsumen dapat mengingat atau mengenali merek atau hanya mengetahui merek tersebut. Asosiasi merek (brand association) adalah segala kesan yang muncul dibenak seseorang terkait dengan ingatannya mengenai suatu merek (Durianto, 2011). Kesan yang muncul dibenak ini mencerminkan pencitraan suatu merek terhadap suatu kesan tertentu dalam kaitannya dengan kebiasaan, gaya hidup, manfaat, atribut produk, geografis, harga, pesaing dan lain-lain (Aaker, 2013).

Persepsi kualitas (perceived quality) adalah persepsi konsumen terhadap keseluruhan kualitas atau keunggulan suatu produk dengan sesuatu yang diharapkan (Durianto, 2011). Loyalitas merek (brand loyalty) merupakan suatu ukuran keterkaitan pelanggan kepada suatu merek (Durianto, 2011). Loyalitas merek akan timbul ketika para konsumen setia pada merek tersebut, kesetiaan akan meningkatkan kekuatan merek itu sendiri baik secara langsung maupun tidak langsung, bahkan dalam beberapa kejadianyang cukup ekstrim, loyalitas merekbisa membuat konsumen loyal tidak memperdulikan kenaikan harga terhadap merek tersebut atau bisa mendukung segala bentuk kampanye yang dibuat oleh merek tersebut. Ekuitas merek yang kuat akan sangat berpengaruh terhadap 
keputusan pembelian, karena bila ekuitas merek tersebut tertanam dengan kuat maka konsumen akan sulit berpindah ke merek lain.

Harga memiliki peran penting dalam menentukan keputusan konsumen untuk membeli barang atau jasa (Gunawan, 2012). Agusty Ferdinand dalam Dinawan (2010), harga merupakan salah satu variabel penting dalam pemasaran dimana harga dapat mempengaruhi konsumen dalam mengambil keputusan untuk membeli suatu produk karena berbagai alasan. Harga merupakan salah satu faktor penentu pembeli dalam menentukan suatu keputusan pembelian terhadap suatu produk maupun jasa, apalagi produk atau jasa yang akan dibeli tersebut merupakan kebutuhan sehari-sehari seperti makanan, minuman dan kebutuhan pokok lainnya, pembeli akan sangat memperhatikan harganya menurut Ghanimata \& Kamal (2012).

Kualitas pelayanan adalah faktor yang menentukan tingkat keberhasilan suatu perusahaan dimana kemampuan perusahaan dalam memberikan pelayanan yang berkualitas kepada konsumen dan sebagai strategi perusahaan untuk mempertahankan diri dan mencapai kesuksesan dalam menghadapi persaingan (Lupiyoadi, 2013). Kualitas pelayanan berfokus pada upaya pemenuhan kebutuhan pelanggan serta ketepatan penyampaian untuk mengimbangi harapan pelanggan. Kopi merupakan salah satu minuman yang sangat digemari oleh masyarakat Indonesia. Kopi bukan hanya dikenal sebagai minuman untuk menambah energi dalam aktivitas sehari-hari, namun telah menjadi gaya hidup yang menjadi ciri khas kehidupan di perkotaan. Kopi menjadi salah satu minuman yang paling banyak dikonsumsi, hal ini terlihat dari pesatnya peningkatan jumlah coffee shop (Buku Peluang Usaha IKM). Peningkatan konsumsi masyarakat terhadap minuman kopi membuat banyak coffee shop berlomba untuk menarik minat konsumen dengan melihat adanya peluang untuk masuk ke pasar yang kompetitif dan dapat menguasai pasar. Perusahaan yang masuk ke lingkungan kompetitif harus siap untuk bersaing dengan perusahaan lainnya dan terus berinovasi menciptakan minuman kopi dengan berbagai manfaat yang akan dirasakan konsumen.

Starbucks merupakan salah satu brand coffee shop yang cukup dikenal di banyak kalangan usia. Starbucks telah berkembang 
pesat dari sebuah kedai kecil di Seattle dengan lebih dari 17.000 gerai di seluruh dunia dan menjadi perusahaan multinasional dalam waktu kurang dari 40 tahun. Starbucks membuka gerai pertamanya di Indonesia pada tahun 2002 di Plaza Jakarta dengan jumlah yang saat itu hanya mencapai 10 gerai. Starbucks memiliki 326 gerai kopi yang tersebar di kota-kota besar Indonesia (starbucks.co.id).

Starbucks sebagai café kopi di Indonesia secara konsisten sejak tahun 20122018 berada pada posisi tertinggi untuk Top Brand Index (TBI) yang terkait dengan café kopi dibandingkan dengan merek lainnya. Starbucks memperoleh index sebesar 51,9 persen lebih unggul dari merek lain yaitu The Coffee Bean \& Tea Leaf yang memperoleh index sebesar 8,6 persen dan Ngopi doeloe memperoleh index sebesar 1,7 persen (Top Brand Awards, 2018). Top Brand merupakan penghargaan yang diberikan kepada merek-merek terbaik pilihan konsumen.

Gerai Starbucks di Bali tersebar di kota Denpasar dan Badung. Di kota Denpasar, Starbucks membuka beberapa gerai yang terletak di Jalan Gatot Subroto Tengah, Plaza Renon Mall dan Level 21 Mall dan di kota
Badung gerai Starbucks terletak di Mall Bali Galeri, Beachwalk Mall. Starbucks Reserve Dewata yang terletak di Jalan Sunset Road No. 77 Seminyak-Kuta, Bali merupakan gerai kopi Starbucks terbesar di Asia Tenggara. Starbucks Reserve Dewata berkomitmen untuk menyajikan pengalaman minum kopi terbaik di dunia. Pengunjung datang tidak sekedar minum kopi tetapi dapat belajar bagaimana biji kopi diproses mulai dari pemilahan, pemanggangan hingga penyajiannya. Gerai Starbucks ini melayani 100 jenis minuman, makanan dan beragam merchandise khas Bali. Selain adanya fasilitas interaktif, gerai ini juga dilengkapi dengan dekorasi dan interior yang membuat para pengunjung nyaman berada disana.

Coffee shop saat ini telah menjadi suatu bisnis yang berkembang dengan pesat. Starbucks sebagai salah satu perintis konsep kedai kopi modern yang menyediakan hidangan kopi siap minum dengan berbagai rasa mulai dari minuman panas espresso, frappucino blended dan makanan ringan seperti cake, cookies, sandwich. Selain menyediakan kopi dan makanan ringan, Starbucks juga menjual mug atau gelas dan tumbler. Starbucks berinovasi dengan varian rasa berbeda dalam 
setiap musim agar tidak kalah saing dengan coffee shop lain seperti Excelso, Coffee Bean \& Tea Leaves dan masih banyak lagi dimana semua itu hampir menyajikan dengan menu yang tak jauh berbeda. Strategi Starbucks dalam meningkatkan keputusan pembelian konsumen salah satunya dengan pemberian diskon dan promo "buy one get one free" pada hari tertentu. Berdasarkan uraian latar belakang masalah, maka penulis melakukan penelitian mengenai pengaruh ekuitas merek, harga dan kualitas pelayanan terhadap keputusan pembelian di gerai Starbucks Bali. Starbucks dipilih sebagai subjek penelitian karena Starbucks dianggap menarik untuk diteliti, karena dilihat dari kesuksesan Starbucks sebagai salah satu perintis coffee shop dengan konsep modern saat ini.

Keputusan pembelian adalah suatu proses pendekatan penyelesaian masalah yang terdiri dari pengenalan masalah, mencari informasi, beberapa penilaian alternatif, membuat keputusan membeli dan perilaku setelah membeli yang dilalui konsumen (Kotler \& Armstrong, 2012). Menurut Swastha (2008), keputusan pembelian merupakan proses dalam pembelian yang nyata apakah membeli atau tidak. Studi mengenai perilaku konsumen juga meliputi analisis faktor-faktor yang mempengaruhi keputusan membeli dan penggunaan produk. Konsumen didalam membuat keputusan memiliki tujuan yang harus dipenuhi atau dipuaskan. Kotler \& Keller (2007) menyatakan bahwa dalam suatu pembelian yang dilakukan oleh konsumen dipengaruhi oleh beberapa faktor diantaranya adalah faktor budaya, faktor sosial (kelompok acuan, keluarga, peran dan status), pribadi (usia dan siklus hidup keluarga, pekerjaan dan lingkungan ekonomi, gaya hidup, kepribadian), psikologis (motivasi, persepsi, pembentukan sikap, integrasi).

Selain itu juga dalam hubungannya dengan keputusan pembelian ada sejumlah pihak yang akan sangat berpengaruh dalam proses pengambilan keputusan yaitu : Pencetus (initiator) adalah individu yang pertama kali menyadari akan kebutuhan yang belum terpenuhi dan mempunyai inisiatif untuk mengusulkan pembelian suatu produk atau jasa tertentu, pemberi pengaruh (influencer) adalah orang yang berperan memberi pengaruh karena pandangannya dapat mempengaruhi keputusan pembelian, pengambil keputusan (decider) adalah seseorang yang memutuskan untuk 
mengambil keputusan apakah akan membeli atau tidak, pembeli (buyer) adalah orang yang membeli, dan pemakai (user) adalah pengguna produk yang dibeli.

Sipayung \& Sinaga (2017) menyatakan keputusan pembelian konsumen adalah pemikiran yang dilakukan konsumen untuk merencanakan pembelian beberapa produk dengan merek tertentu. Konsumen akan mencari informasi produk yang diperlukan sebelum melakukan keputusan pembelian. Proses keputusan pembelian sudah lama dimulai sebelum keputusan pembelian sebenarnya terjadi.

Amrullah dan Agustin (2016) menyatakan bahwa keputusan pembelian adalah tahapan dari pemilihan salah satu produk dari beberapa alternatif penyelesaian masalah dengan tindak lanjut yang nyata. Keputusan pembelian konsumen merupakan keseluruhan dari tahapan yang dilakukan konsumen untuk mendapatkan produk dan layanan yang dibutuhkan untuk memenuhi kebutuhan sehari-hari (Ruslim dan Tumewu, 2015).

Schiffman dan Kanuk (2008:485) menyatakan bahwa keputusan pembelian adalah seleksi terhadap dua pilihan alternatif atau lebih konsumen sebelum melakukan pembelian terhadap suatu produk. Kosumen akan mempertimbangkan banyak hal sebelum melakukan keputusan pembelian sehingga penting bagi pemasar perlu mengetahui proses tersebut.

Kotler \& Armstrong

menyatakan terdapat beberapa tahap dalam proses keputusan pembelian yaitu : Pengenalan masalah yaitu proses pembelian dimulai saat pembeli mengenali sebuah masalah atau kebutuhan. Kebutuhan tersebut dapat dicetuskan oleh rangsangan internal atau eksternal, pencarian informasi yaitu konsumen yang tergugah kebutuhannya akan terdorong untuk mencari informasi yang lebih banyak, evaluasi alternatif yaitu mengevaluasi berbagai alternatif yang ada dalam konteks kepercayaan utama tentang konsekuensi yang relevan dan mengkombinasikan pengetahuan tersebut untuk membuat keputusan, keputusan pembelian yaitu calon pembeli menentukan apa dan dimana produk pilihan mereka akan dibeli, perilaku pasca pembelian yaitu setelah melakukan keputusan pembelian terhadap suatu produk, maka perilaku selanjutnya akan ditentukan dari kepuasaan atau manfaat yang diperoleh 
konsumen dari produk yang dikonsumsinya sejauh mana pelanggan bersedia membayar tersebut. lebih untuk produk tersebut. Ekuitas merek

Setiadi

$(2015: 341)$

menyatakan pengambilan keputusan adalah proses pengintegrasian yang mengkombinasikan pengetahuan untuk mengevaluasi dua atau lebih perilaku alternatif untuk memilih salah satu diantaranya. Pengukuran keputusan pembelian menggunakan tiga indikator yaitu : Suprapti (2010) prioritas utama adalah pilihan yang diutamakan konsumen terhadap suatu merek, kecepatan memutuskan adalah waktu yang diperlukan konsumen untuk mengambil keputusan dalam memilih suatu merek, kemudahan menjangkau adalah lokasi yang mudah dijangkau oleh konsumen.

Ekuitas merek adalah seperangkat aset dan liabilitas merek yang terkait dengan suatu merek, nama, simbol yang mampu menambah atau mengurangi nilai yang diberikan oleh sebuah produk atau jasa baik pada perusahaan maupun konsumen (Aaker, 2013). Menurut Kotler \& Armstrong (2012) ekuitas merek adalah pengaruh deferensial positif bahwa jika pelanggan mengenal nama merek, pelanggan tersebut akan merespon produk atau jasa tersebut. Satu ukuran ekuitas merek adalah adalah nilai tambah yang diberikan pada produk dan jasa. Nilai ini bisa dicerminkan dalam cara konsumen berpikir, merasa dan bertindak terhadap merek, harga, pangsa pasar dan profitabilitas yang dimiliki perusahaan.

Ekuitas merek mampu memberikan beberapa keunggulan seperti peluang dan kekuatan komunikasi (Omer, 2014). Brand equity merupakan aktiva tak berwujud yang memiliki peranan penting dan dapat memberikan keunggulan kompetitif bagi perusahaan (Shahin, 2012). Ekuitas merek adalah seperangkat asosiasi dan perilaku yang dimiliki oleh pelanggan merek, anggota saluran distribusi dan perusahaan yang memungkinkan suatu merek mendapatkan kekuatan, daya tahan dan keunggulan yang dapat membedakannya dengan merek pesaing (Soebianto, 2014).

Ekuitas merek merupakan aset tak berwujud yang penting, yang memiliki nilai psikologis dan keuangan bagi perusahaan (Kotler \& Keller, 2007). Ekuitas merek terdiri dari empat elemen yaitu kesadaran merek (brand awareness), asosiasi merek (brand association), persepsi kualitas (perceived 
quality) dan loyalitas merek (brand loyalty).

Kesadaran merek adalah kemampuan konsumen untuk mengenali dan mengingat kembali suatu merek merupakan bagian dari kategori produk tertentu (Aaker, 2013). Kesadaran merek merupakan kemampuan konsumen untuk mengenali atau mengingat kembali suatu merek ketika berpikir mengenai suatu kategori produk tertentu dan terdapat kemudahan saat nama tersebut dimunculkan (Shimp, 2014:97). Konsumen cenderung membeli merek yang sudah dikenal karena merasa aman dengan sesuatu yang sudah dikenal. Dengan kata lain, sebuah merek yang dikenal mempunyai kemungkinan bisa diandalkan, kemantapan dalam bisnis dan kualitas yang dapat dipertanggungjawabkan.

Menurut Durianto (2011) kesadaran merek adalah kesanggupan seorang calon pembeli untuk mengenali atau mengingat kembali bahwa suatu merek merupakan bagian dari kategori produk tertentu. Kesadaran merek juga merupakan kesanggupan sekumpulan konsumen untuk mengetahui kembali tentang keberadaan suatu merek. Pengukuran kesadaran merek menggunakan lima indikator yaitu: (Aaker, 2013) ketidaksadaran merek (unware of brand) adalah konsumen tidak menyadari akan adanya suatu merek, pengenalan merek (brand recognition) adalah konsumen telah mengenal adanya suatu merek, pengingatan kembali (brand recall) adalah konsumen mampu mengingat kembali suatu merek, puncak pikiran (top of mind) adalah merek utama yang ada dibenak konsumen.

Asosiasi merek adalah suatu hal yang mencerminkan pencitraan suatu merek terhadap suatu kesan tertentu dalam kaitannya dengan kebiasaan, gaya hidup, manfaat, atribut produk, geografis, harga, pesaing dan lain-lain (Aaker, 2013). Kesan-kesan yang terkait dengan merek akan semakin meningkat dengan banyaknya pengalaman konsumen dalam mengkonsumsi suatu merek atau dengan semakin seringnya penampakan suatu merek dalam startegi komunikasinya. Asosiasi merek akan membantu konsumen dan memberikan alasan pembelian terhadap konsumen terkait dengan atribut merek dan manfaatnya sehingga mereka melakukan keputusan pembelian (Chen, 2013). Asosiasi merek dapat menciptakan suatu nilai bagi perusahaan dan para pelanggan karena dapat membantu penyusunan informasi untuk membedakan merek yang satu dengan yang lain 
(Silaban dan Marselia, 2016).

Pengukuran asosiasi merek menggunakan lima indikator yaitu: Humdiana (2005)manfaat psikologis adalah perasaan yang ditimbulkan konsumen pada suatu merek, gaya hidup/kepribadian adalah pola hidup konsumen yang diekspresikan dalam aneka karakteristik kepribadian yang hampir sama, citra merek adalah persepsi positif konsumen terhadap suatu merek, kredibilitas adalah kemampuan suatu merek yang dapat menimbulkan kepercayaan konsumen. Menurut Tjiptono (2011:100) kredibilitas merek adalah seberapa jauh sebuah merek dinilai kredibel dalam hal expertise (kompeten, inovatif, pemimpin pasar), trustworthiness (bisa diandalkan, selalu mengutamakan kepentingan pelanggan) dan likeability (menarik, fun, memang layak untuk dipilih dan digunakan).

Persepsi kualitas adalah persepsi konsumen terhadap keseluruhan kualitas atau keunggulan suatu produk dengan sesuatu yang diharapkan (Durianto, 2011). Persepsi kualitas yang positif akan mendorong keputusan pembelian dan menciptakan loyalitas terhadap produk tersebut. Sebaliknya, jika persepsi kualitas konsumen negatif maka produk tersebut tidak akan disukai dan tidak akan bertahan lama (Durianto, 2011). Persepsi kualitas memiliki peranan penting dalam membangun merek dan dapat menjadi alasan yang penting pada pembelian merek mana yang akan dipertimbangkan untuk dibeli.

Persepsi kualitas meliputi segala sesuatu yang berkaitan dengan bagaimana suatu merek dapat dipersepsikan sehingga dengan diketahuinya persepsi pelanggan terhadap kualitas dari merek yang dimiliki oleh perusahaan maka perusahaan dapat menentukan langkah-langkah apa yang dapat diambil untuk memperkuat persepsi pelanggan terhadap merek tersebut (Wijaya, 2013). Pengukuran persepsi kualitas menggunakan lima indikator yaitu: (Aaker, 2013) kinerja (performance) adalah manfaat suatu merek sebagai ciri-ciri utama yang dipertimbangkan konsumen, fitur (features) adalah jenis atau produk varian yang disediakan pada suatu merek, kesesuaian (conformance) adalah tingkat kesesuaian suatu merek terhadap spesifikasi yang telah ditetapkan sebelumnya berdasarkan keinginan konsumen, daya tahan (durability) adalah kemampuan suatu merek dalam memenuhi kebutuhan konsumen, pelayanan (serviceability) adalah kecepatan 
pelayanan yang diberikan kepada konsumen.

Loyalitas merek muncul dari persepsi dan kecintaan terhadap suatu merek yang berpengaruh pada keterkaitan konsumen dengan suatu merek produk (Aaker, 2013). Loyalitas merek akan berdampak baik bagi konsumen karena akan timbul rasa ingin membeli kembali terhadap suatu merek produk tertentu, walaupun dihadapkan pada banyak alternatif merek produk pesaing yang menawarkan karakteristik produk yang lebih unggul (Aaker, 2013). Loyalitas merek menunjukkan kesetiaan pelanggan pada merek tertentu dengan komitmen yang tinggi dan berniat untuk terus membelinya dimasa mendatang saat konsumen tersebut membutuhkan (Listiana, 2015).

Loyalitas merek merupakan ukuran kedekatan pelanggan pada suatu merek dan perasaan positif terhadap suatu merek. Itulah sebabnya pelanggan akan cenderung menggunakan produk secara teratur. Pembelian ulang sangat dipengaruhi tingkat loyalitas merek yang dimiliki oleh pelanggan. Menurut Durianto (2011) terdapat lima tingkatan loyalitas merek, yaitu : Switcher or price buyer merupakan tingkatan loyalitas yang paling dasar. Pembeli tidak loyal sama sekali terhadap suatu merek.
Bagi pembeli tersebut, merek apapun dianggap memadai. Merek memainkan peran yang kecil dalam keputusan pembelian, apapun yang diobral atau menawarkan kenyamanan akan lebih disukai. Habitual buyer merupakan pembeli yang puas dengan produk atau setidaknya tidak mengalami ketidakpuasan dan membeli merek produk tertentu karena kebiasaan. Pembeli seperti ini tidak terdapat dimensi ketidakpuasan yang cukup untuk menstimulasi suatu peralihan merek terutama jika peralihan tersebut membutuhkan usaha, karena tidak ada alasan bagi mereka untuk memperhitungkan berbagai alternatif. Satisfied buyer merupakan orangorang yang puas, namun mereka memikul biaya peralihan (switching cost) yaitu biaya dalam waktu, uang atau risiko kinerja sehubungan dengan tindakan beralih merek. Menarik minat para pembeli yang termasuk dalam golongan ini, para kompetitor perlu mengawasi biaya peralihan dengan menawarkan bujukan untuk beralih atau dengan tawaran suatu manfaat yang cukup besar sebagai kompensasi. Liking the brand merupakan pembeli yang sungguhsungguh menyukai merek-merek tersebut. Preferensi mereka mungkin dilandasi pada suatu asosiasi seperti symbol, rangkaian 
pengalaman dalam menggunakan produk atau persepsi kualitas yang tinggi. Committed buyer merupakan pelanggan setia. Mereka mempunyai suatu kebanggaan untuk menjadi pengguna dari suatu merek. Merek tersebut sangat penting bagi mereka, baik dari segi fungsi maupun sebagai suatu ekspresi mengenai siapa mereka sebenarnya. Rasa percaya mereka mendorong mereka merekomendasikan merek tersebut kepada orang lain.

Pengukuran loyalitas merek menggunakan empat indikator yaitu: (Putra,2013 ;Astuti dan Cahyadi,2007) komitmen adalah komitmen untuk tetap konsisten pada suatu merek, rekomendasi adalah kemauan konsumen untuk merekomendasikan suatu merek kepada pihak lain, membayar lebih mahal adalah kemauan konsumen untuk membayar lebih mahal pada suatu merek, mengikuti informasi adalah keinginan pelanggan untuk mengikuti perkembangan informasi suatu merek.

Harga merupakan sesuatu yang diserahkan dalam pertukaran untuk mendapatkan suatu barang maupun jasa. Harga khususnya merupakan pertukaran uang bagi barang atau jasa juga pengorbanan waktu karena menunggu untuk memperoleh barang atau jasa menurut
Lupiyoadi dalam Ghanimata \& Kamal (2012). Harga merupakan salah satu faktor penentu pembeli dalam menentukan suatu keputusan pembelian terhadap suatu produk maupun jasa, apalagi apabila produk atau jasa yang akan dibeli tersebut merupakan kebutuhan sehari-sehari seperti makanan, minuman dan kebutuhan pokok lainnya, pembeli akan sangat memperhatikan harganya menurut Ghanimata \& Kamal (2012). Menurut Satit (2012), harga adalah salah satu unsur bauran pemasaran yang mempengaruhi keputusan pembelian pelanggan, sebagai hasil dari penelitiannya, penjual bisa mempertahankan pelanggan setia dengan menawarkan harga yang menarik dan kompetitif dan memberikan potongan harga yang spesial.

Dinawan (2010), harga merupakan salah satu variabel penting dalam pemasaran dimana harga dapat mempengaruhi konsumen dalam mengambil keputusan untuk membeli suatu produk karena berbagai alasan. Menurut Monroe dalam Sari (2012), harga merupakan pengorbanan ekonomis yang dilakukan pelanggan untuk memperoleh produk atau jasa. Alasan ekonomis akan menunjukkan harga yang rendah atau harga terlalu berkompetisi 
merupakan salah satu pemicu penting untuk meningkatkan kinerja pemasaran tetapi alasan psikologis dapat menunjukkan bahwa harga justru merupakan indikator kualitas dan karena itu dirancang sebagai salah satu instrumen penjualan sekaligus sebagai instrument kompetisi yang menentukan.

Pengukuran harga menggunakan empat indikator menurut yaitu: Kotler \& Armstrong (2012) harga terjangkau adalah harga yang ditetapkan pada suatu produk sesuai dengan daya beli konsumen, membandingkan harga adalah kebiasaan konsumen membandingkan merek yang satu dengan yang lainnya, kesesuaian harga dengan kualitas produk adalah harga yang ditetapkan sesuai dengan kualitas yang ditawarkan, kesesuaian harga dengan manfaat adalah harga yang ditetapkan sesuai dengan manfaat yang diberikan.

Kualitas pelayanan adalah faktor yang menentukan tingkat keberhasilan suatu perusahaan dimana kemampuan perusahaan dalam memberikan pelayanan yang berkualitas kepada konsumen dan sebagai strategi perusahaan untuk mempertahankan diri dan mencapai kesuksesan dalam menghadapi persaingan (Lupiyoadi, 2013). Kualitas variabel ekuitas merek memiliki pengaruh

pelayanan berfokus pada upaya pemenuhan kebutuhan pelanggan serta ketepatan penyampaian untuk mengimbangi harapan pelanggan.

Pengukuran kualitas pelayanan menggunakan lima indikator yaitu : (Tjiptono,2012:198) Bukti fisik (tangibles) yaitu berupa penampilan fisik, perlengkapan dan material yang digunakan perusahaan serta penampilan karyawan, kehandalan (reliability) yaitu kemampuan perusahaan untuk memberikan layanan yang akurat sejak pertama kali tanpa membuat kesalahan apapun dan menyampaikan jasanya sesuai dengan waktu yang disepakati, ketanggapan (responsiveness) yaitu kesediaan para karyawan untuk membantu para konsumen dan memberikan pelayanan dengan tanggap dan cepat, jaminan (assurance) yaitu perilaku karyawan mampu menumbuhkan kepercayaan pelanggan terhadap perusahaan dan perusahaan bisa menciptakan rasa aman bagi para pelanggannya, empati (empathy) yang meliputi kemudahan dalam melakukan hubungan komunikasi yang baik dan memahami kebutuhan para konsumen.

Widhiarta (2015) menyatakan bahwa 
positif dan signifikan terhadap keputusan harga berpengaruh positif terhadap keputusan pembelian. Penelitian yang dilakukan oleh pembelian. Fernando (2018) menyatakan bahwa Winatapradja (2013) menyatakan ekuitas harga memiliki pengaruh positif dan signifikan merek memiliki pengaruh positif dan signifikan terhadap keputusan pembelian. Berdasarkan terhadap keputusan pembelian. Soebianto hasil kajian empiris, maka dapat disusun (2014) menyatakan bahwa ekuitas merek hipotesis sebagai berikut:

memiliki pengaruh positif dan signifikan $\mathrm{H}_{2} \quad$ : Harga berpengaruh positif signifikan terhadap keputusan pembelian. Penelitian yang terhadap keputusan pembelian dilakukan Sari (2015) menyatakan ekuitas Penelitian yang dilakukan Alfredo merek memiliki pengaruh positif dan signifikan dan Edward (2015) dalam penelitiannya terhadap keputusan pembelian. Berdasarkan menyatakan bahwa kualitas pelayanan hasil kajian empiris, maka dapat disusun memiliki pengaruh positif dan signifikan hipotesis sebagai berikut : terhadap keputusan pembelian. Denny Aditya $\mathrm{H}_{1} \quad$ : Ekuitas merek berpengaruh positif (2017) dalam penelitiannya menyatakan bahwa signifikan terhadap keputusan pembelian kualitas pelayanan memiliki pengaruh positif terhadap keputusan pembelian. Septiyaningsih

Dawood (2015) menyatakan bahwa variabel harga memiliki pengaruh positif dan (2016) dan Satya (2012) dalam penelitiannya mengemukakan bahwa kualitas pelayanan signifikan terhadap keputusan pembelian. merupakan variabel yang pengaruhnya Penelitian yang dilakukan oleh Aswan (2013) paling kuat dan dominan terhadap keputusan menyatakan bahwa harga memiliki pengaruh pembelian. Penelitian yang dilakukan Khairul positif dan signifikan terhadap keputusan Hakim (2017) menyatakan bahwa kualitas pembelian. Penelitian yang dilakukan Hariadi pelayanan memiliki pengaruh positif dan (2013) menyatakan bahwa harga memiliki signifikan terhadap keputusan pembelian. pengaruh positif dan signifikan terhadap Berdasarkan hasil kajian empiris, maka dapat keputusan pembelian. Penelitian yang disusun hipotesis sebagai berikut: dilakukan Anwar dan Satrio (2015) menyatakan $\mathrm{H}_{3} \quad$ : Kualitas pelayanan berpengaruh 
positif signifikan terhadap keputusan pembelian

\section{METODE PENELITIAN}

Penelitian ini digolongkan pada penelitian asosiatif. Penelitian asosiatif merupakan penelitian yang bertujuan untuk mengetahui pengaruh ataupun juga hubungan antara dua variabel atau lebih (Sugiyono, 2017). Penggunaan metode ini untuk menganalisis pengaruh ekuitas merek, harga dan kualitas pelayanan terhadap keputusan pembelian di gerai Starbucks.

Lokasi penelitian dilakukan di wilayah Bali. Gerai Starbucks di Bali tersebar di wilayah Badung dan Denpasar. Lokasi penelitian dilakukan pada gerai Starbucks yang terletak di Gatot Subroto, Level 21 Mall, Plaza Renon dan Mall Bali Galeria - Kuta. Objek penelitian yang digunakan untuk penelitian ini adalah ekuitas merek, harga dan kualitas pelayanan terhadap keputusan pembelian di Starbucks.

Jenis-jenis data yang digunakan dalam penelitian ini dapat dibedakan menjadi dua, yaitu sebagai berikut. Data Kuantitatif adalah jenis data yang dinyatakan dalam bentuk angka dan mempunyai satuan hitung. Data kuantitatif yang dikumpulkan dalam penelitian ini adalah data dari hasil tanggapan responden terhadap kuesioner yang diberikan sesuai dengan sampel yang telah ditentukan. Data Kualitatif merupakan data yang tidak dapat dinyatakan kedalam bentuk angka. Data kualitatif yang dikumpulkan adalah data yang dikumpulkan secara langsung kepada konsumen yang tentunya sudah pernah melakukan pembelian di Starbucks.

Adapun sumber data dalam penelitian ini adalah sebagai berikut: Data primer dalam penelitian ini dikumpulkan melalui hasil wawancara dan jawaban dari kuesioner yang disebarkan pada responden atau konsumen yang sudah pernah melakukan pembelian di Starbucks. Data sekunder yang dikumpulkan dalam penelitian ini yaitu sumber yang berasal dari berita-berita online maupun studi empiris mengenai ekuitas merek, harga, kualitas pelayanan dan keputusan pembelian.

Sugiyono (2017) menyatakan bahwa instrumen penelitian yang valid dan reliabel, maka hasil penelitian diharapkan valid dan reliabel juga. Sebelum instrumen digunakan untuk mengumpulkan data, maka instrumen tersebut perlu diuji validitas dan reliabilitasnya terlebih dahulu. Penelitian ini menggunakan 
data primer dengan menyebarkan kuesioner, dengan 10 dari jumlah indikator yang diteliti. untuk mendapatkan hasil yang valid dan reliabel Jumlah indikator yang digunakan dalam dalam pengumpulan data kuesioner maka penelitian ini adalah sebanyak 29 indikator perlu diuji dengan uji validitas dan reliabilitas sehingga ukuran sampel yang layak digunakan instrumen terlebih dahulu.

Responden penelitian ini adalah semua antara 145 sampai dengan 290 unit. Ukuran sampel yang ditentukan dalam penelitian ini konsumen Starbucks di Bali. Sifat populasi penelitian adalah tidak terbatas artinya bahwa adalah sebanyak 145 unit karena jumlah tersebut sudah berada pada batas yang disyaratkan. jumlah populasi konsumen Starbucks tidak Metode pengumpulan data dalam penelitian ini dapat ditentukan, dalam artian identitasnya yaitu dengan melakukan wawancara terstruktur tidak dapat dideteksi.

kepada konsumen dengan menggunakan

Metode penentuan sampel yang kuesioner sebagai pedoman studi kepustakaan. digunakan adalah non-probability sampling dengan pendekatan purposive sampling yaitu teknik penentuan sampel dengan kriteria atau HASIL DAN PEMBAHASAN

Responden dalam penelitian ini pertimbangan tertentu (Sugiyono, 2017). berjumlah 145 responden yang didapat melalui Kriteria penentuan sampel : Responden berusia penyebaran kuesioner secara langsung. minimal 17 tahun. Kriteria ini digunakan karena coffee shop paling banyak dikunjungi kaum muda untuk berkumpul dan menghabiskan waktu untuk bertukar pikiran dan informasi di coffee shop, responden yang sudah pernah melakukan pembelian pada gerai Starbucks di Bali.

(Sugiyono, 2017) mengatakan untuk menghitung ukuran sampel yang representatif Deskripsi dari responden dalam penelitian yang dilakukan ini ditinjau dari beberapa variabel seperti variabel demografi yang digambarkan melalui variabel jenis kelamin, usia, pendidikan terakhir, pekerjaan dan frekuensi membeli.

Tabel 1 menunjukkan deskripsi responden berdasarkan jenis kelamin, didominasi responden perempuan dengan persentase yaitu 58,62 persen dan responden dapat ditentukan dengan setidaknya 5 sampai laki-laki dengan persentase yaitu 41,38 
persen. Deskripsi responden berdasarkan usia, berdasarkan pendidikan terakhir didominasi responden pada rentang usia 17 sampai 25 oleh responden pendidikan akhir sarjana dengan tahun mendominasi dengan persentase 41,38 persentase 51,73 persen, kemudian responden persen yang menandakan bahwa pada rentang berdasarkan pendidikan akhir diploma dengan umur inilah responden lebih memilih Starbucks persentasi 24,13 persen. responden dengan sebagai tempat ngopi. Kemudian diikuti rentan pekerjaan sebagai karyawan swasta dengan usia 26 sampai 34 tahun dengan persentase persentase 6,90 persen.

34,48 persen, rentan usia 35 sampai 43 tahun

Di posisi ketiga responden berdasarkan dengan persentase 13,79 persen. Terakhir yaitu pendidikan akhir SMA/SMK memiliki usia yang lebih dari 44 tahun dengan persentase persentase yaitu 17,24 persen dan terakhir sebesar 10,35 persen.Deskripsi responden responden berdasarkan pendidikan akhir pasca

Tabel 1.

Deskripsi Responden

\begin{tabular}{|c|c|c|c|c|}
\hline No & Variabel & Klasifikasi & $\begin{array}{l}\text { Jumlah } \\
\text { (orang) }\end{array}$ & $\begin{array}{l}\text { Persentase } \\
(\%)\end{array}$ \\
\hline \multirow{4}{*}{1} & \multirow{2}{*}{ Jenis kelamin } & Laki-laki & 60 & 41.38 \\
\hline & & Perempuan & 85 & 58.62 \\
\hline & \multirow[t]{2}{*}{ Jumlah } & & 145 & 100 \\
\hline & & 17-25 tahun & 60 & 41.38 \\
\hline \multirow{3}{*}{2} & \multirow{3}{*}{ Usia } & 26-34 tahun & 50 & 34.48 \\
\hline & & $35-43$ tahun & 20 & 13.79 \\
\hline & & $>44$ tahun & 15 & 10.35 \\
\hline \multirow{6}{*}{3} & \multirow[t]{2}{*}{ Jumlah } & & 145 & 100 \\
\hline & & SMA/SMK & 25 & 17.24 \\
\hline & \multirow{3}{*}{ Pendidikan terakhir } & Diploma & 35 & 24.13 \\
\hline & & Sarjana & 75 & 51.73 \\
\hline & & Pasca Sarjana & 10 & 6.90 \\
\hline & \multirow[t]{2}{*}{ Jumlah } & & 145 & 100 \\
\hline \multirow{4}{*}{4} & & Pelajar & 25 & 17.24 \\
\hline & \multirow{3}{*}{ Pekerjaan } & Mahasiswa & 85 & 58.62 \\
\hline & & Karyawan Swasta & 10 & 6.90 \\
\hline & & PNS & 25 & 17.24 \\
\hline \multirow{5}{*}{5} & Jumlah & & 145 & 100 \\
\hline & Frekuensi membeli & Dua kali & 30 & 20.69 \\
\hline & (dalam dua bulan & Tiga kali & 50 & 34.48 \\
\hline & terakhir) & Lebih dari tiga kali & 65 & 44.83 \\
\hline & Jumlah & & 145 & 100 \\
\hline
\end{tabular}

Sumber: data diolah, 2019 
sarjana memiliki persentase 6,90 persen. Cronbach $>0,60$. Adapun hasil dari uji Deskripsi responden berdasarkan pekerjaan reliabilitas dapat ditunjukkan pada Tabel 3. didominasi mahasiswa dengan persentase 58,62 Suatu instrumen dikatakan reliabel, kemudian diikuti responden dengan pekerjaan jika instrumen tersebut memiliki nilai Alpha sebagai pelajar memiliki persentase yang sama Cronbach $>0,60$. Hasil uji reliabilitas yang dengan PNS yaitu 17,24 persen. Terakhir yaitu disajikan dalam Tabel 3 menunjukkan bahwa Berdasarkan deskripsi responden berdasarkan setiap variabel memiliki nilai koefisien Alpha frekuensi membeli dalam dua bulan terakhir Cronbach $>0,6$. Hal ini dapat dikatakan bahwa didominasi lebih dari tiga kali dengan persentase semua variabel dalam penelitian ini adalah 44,83 persen. Kemudian frekuensi membeli reliabel.

dalam dua bulan terakhir sebanyak tiga kali dengan persentase 34,48 persen dan terakhir frekuensi membeli dalam dua bulan terakhir sebanyak dua kali dengan persentase 20,69 persen.

Suatu instrumen dikatakan valid jika korelasi antara skor faktor dengan skor total bernilai positif dan nilainya lebih dari $0,30(\mathrm{r}>$ $0,3)$. Berikut tabel hasil pengujian validitas.

Hasil uji validitas pada Tabel 2 Uji asumsi klasik dilakukan dengan tujuan untuk memastikan hasil yang diperoleh memenuhi asumsi dasar di dalam analisis regresi. Hasil uji asumsi klasik yang dilakukan dalam penelitian ini adalah uji normalitas, uji multikoliniearitas, dan uji heterokedastisitas. Hasil dari uji asumsi klasik yang diolah dengan bantuan software SPSS for Windows disajikan sebagai berikut.

Uji ini bertujuan untuk mengetahui menunjukkan bahwa seluruh variabel memiliki apakah residual dari model regresi yang dibuat nilai koefisien korelasi dengan skor total seluruh berdistribusi normal atau tidak.Untuk menguji item pernyataan $>0,30$. Hal ini menunjukkan bahwa butir-butir pernyataan dalam instrumen penelitian tersebut valid. apakah data yang digunakan normal atau tidak dapat dilakukan dengan menggunakan uji Kolmogorov Smirnov. Apabila koefisien Asymp.

Suatu instrumen dikatakan reliabel, Sig. (2-tailed) >0,05 maka data tersebut akan jika instrumen tersebut memiliki nilai Alpha berdistribusi normal. 
Tabel 2.

Hasil Uji Validitas

\begin{tabular}{|c|c|c|c|c|}
\hline No & Variabel & Item Pernyataan & $\begin{array}{l}\text { Korelasi } \\
\text { Item Total }\end{array}$ & Ket \\
\hline \multirow{3}{*}{1} & \multirow{3}{*}{$\begin{array}{l}\text { Keputusan Pembelian } \\
\text { (Y) }\end{array}$} & Prioritas utama & 0.800 & Valid \\
\hline & & Kecepatan memutuskan & 0.918 & Valid \\
\hline & & Kemudahan menjangkau & 0.767 & Valid \\
\hline \multirow[t]{19}{*}{2} & \multicolumn{4}{|l|}{ Ekuitas Merek $\left(\mathrm{X}_{1}\right)$} \\
\hline & \multirow{5}{*}{ Kesadaran Merek $\left(\mathrm{X}_{1.1}\right)$} & Ketidaksadaran merek & 0.703 & Valid \\
\hline & & Pengenalan merek & 0.691 & Valid \\
\hline & & Pengingatan kembali & 0.873 & Valid \\
\hline & & Puncak pikiran (top of mind) & 0.676 & Valid \\
\hline & & Manfaat psikologis & 0.788 & Valid \\
\hline & \multirow[t]{5}{*}{ Asosiasi Merek $\left(\mathrm{X}_{1.2}\right)$} & Gaya hidup/kepribadian & 0.785 & Valid \\
\hline & & Citra merek & 0.820 & Valid \\
\hline & & Kredibilitas & 0.581 & Valid \\
\hline & & Kinerja & 0.796 & Valid \\
\hline & & Fitur & 0.915 & Valid \\
\hline & \multirow[t]{4}{*}{ Persepsi Kualitas $\left(\mathrm{X}_{1.3}\right)$} & Kesesuaian & 0.807 & Valid \\
\hline & & Daya tahan & 0.836 & Valid \\
\hline & & Kemampuan pelayanan & 0.813 & Valid \\
\hline & & Komitmen & 0.870 & Valid \\
\hline & \multirow[t]{4}{*}{ Loyalitas Merek $\left(\mathrm{X}_{1.4}\right)$} & Rekomendasi & 0.813 & Valid \\
\hline & & Membayar lebih mahal & 0.800 & Valid \\
\hline & & Mengikuti informasi & 0.764 & Valid \\
\hline & & Harga terjangkau & 0.888 & Valid \\
\hline \multirow[t]{6}{*}{3} & \multirow[t]{6}{*}{ Harga $\left(\mathrm{X}_{2}\right)$} & Membandingkan harga & 0.657 & Valid \\
\hline & & Kesesuaian harga dengan & 0.837 & Valid \\
\hline & & kualitas & 0.892 & Valid \\
\hline & & $\begin{array}{l}\text { Kesesuaian harga dengan } \\
\text { manfaat }\end{array}$ & & \\
\hline & & Bukti fisik & 0.858 & Valid \\
\hline & & Kehandalan & 0.855 & Valid \\
\hline \multirow[t]{3}{*}{4} & \multirow{3}{*}{$\begin{array}{l}\text { Kualitas } \\
\left(\mathrm{X}_{3}\right)\end{array}$} & Ketanggapan & 0.732 & Valid \\
\hline & & Jaminan & 0.833 & Valid \\
\hline & & Empati & 0.777 & Valid \\
\hline
\end{tabular}

Sumber: data diolah,2019

Tabel 3

Hasil Uji Reliabilitas

\begin{tabular}{llll}
\hline No. & Variabel & Cronbach's Alpha & Ket \\
\hline 1 & Ekuitas Merek $\left(\mathrm{X}_{1}\right)$ & 0.940 & Reliabel \\
2 & Harga $\left(\mathrm{X}_{2}\right)$ & 0.829 & Reliabel \\
3 & Kualitas Pelayanan $\left(\mathrm{X}_{3}\right)$ & 0.860 & Reliabel \\
4 & Keputusan Pembelian $(\mathrm{Y})$ & 0.763 & Reliabel \\
\hline
\end{tabular}

Sumber: data diolah,2019 
Tabel 4.

Hasil Uji Normalitas Struktur 1

\begin{tabular}{ll}
\hline & Unstandardized Residual \\
\hline $\mathrm{N}$ & 145 \\
Kolmogorov-Smirnov & 0.836 \\
Asymp.Sig.(2-tailed) & 0.486 \\
\hline
\end{tabular}

Sumber: data diolah,2019

Tabel 5.

Hasil Uji Multikolinearitas

\begin{tabular}{lll}
\hline Variabel & Tolerance & VIF \\
\hline Ekuitas Merek & 0.334 & 2.994 \\
Harga & 0.383 & 2.613 \\
Kualitas Pelayanan & 0.344 & 2.902 \\
\hline
\end{tabular}

Sumber: data diolah,2019

Berdasarkan Tabel 4 dapat dilihat tolerance dan VIF dari variabel ekuitas merek, bahwa nilai Kolmogorov Smirnov (K-S) sebesar harga dan kualitas pelayanan menunjukan nilai 0,836, sedangkan Asymp.Sig. (2-tailed) sebesar VIF < 10 yang berarti model persamaan regresi 0,486. Hasil tersebut mengindikasikan bahwa bebas dari multikolinearitas.

model persamaan regresi tersebut berdistribusi Uji yang menilai apakah ada normal karena nilai Asymp. Sig.(2-tailed) lebih ketidaksamaan varian dari residual untuk semua besar dari nilai alpha 0,05 . pengamatan pada model regresi linear. Uji ini

Uji ini bertujuan untuk menguji merupakan salah satu dari uji asumsi klasik yang apakah pada model regresi ditemukan adanya harus dilakukan pada regresi linear. Apabila korelasi antar variabel independen. Adanya asumsi heteroskedastistas tidak terpenuhi, maka multikolinearitas dapat dilihat dari nilai model regresi dinyatakan tidak valid sebagai alat tolerance atau variance inflation factor (VIF). peramalan dan pengujian ini dilakukan dengan Jika nilai tolerance $>0,10$ atau VIF $<10$, maka Uji Glejser. Jika signifikansinya diatas 0,05 dikatakan tidak ada multikolinearitas. maka tidak mengandung heteroskedastistas.

Berdasarkan Tabel 5 dapat dilihat bahwa nilai 
Tabel 6.

Hasil Uji Heteroskedastistas

\begin{tabular}{|c|c|c|c|c|c|}
\hline \multirow[t]{2}{*}{ Model } & \multicolumn{2}{|c|}{$\begin{array}{l}\text { Unstandardized } \\
\text { Coefficients }\end{array}$} & \multirow{2}{*}{$\begin{array}{l}\text { Standardized } \\
\text { Coefficients } \\
\text { Beta }\end{array}$} & \multirow[t]{2}{*}{$\mathbf{T}$} & \multirow[t]{2}{*}{ Sig. } \\
\hline & $\mathbf{B}$ & Std. Error & & & \\
\hline (Constant) & 0.602 & 0.146 & & 4.127 & 0.000 \\
\hline Ekuitas Merek & -0.033 & 0.067 & -0.070 & -0.486 & 0.627 \\
\hline Harga & 0.007 & 0.058 & 0.016 & 0.122 & 0.903 \\
\hline Kualitas Pelayanan & -0.045 & 0.057 & -0.113 & -0.796 & 0.427 \\
\hline
\end{tabular}

Sumber: data diolah,2019

Pada Tabel 6 dapat dilihat bahwa nilai variabel bebas. Analisis ini juga dapat menduga signifikansi dari variabel ekuitas merek sebesar arah dari hubungan tersebut serta mengukur 0,627, variabel harga sebesar 0,903 dan variabel derajat keeratan hubungan antara satu variabel kualitas pelayanan sebesar 0,427. Nilai tersebut terikat dengan satu variabel bebas. Berikut hasil $>0,05$ yang berarti tidak terdapat pengaruh analisis regresi dengan program SPSS.

antara variabel bebas terhadap absolute residual. Persamaan regresi yang digunakan Sehingga model yang dibuat tidak mengandung dalam penelitian ini dapat ditulis sebagai berikut heteroskedastistas.

$Y=0,346 X_{1}+0,237 X_{2}+0,267 X_{3}+e \ldots \ldots(3)$

Analisis regresi linier berganda Berdasarkan persamaan regresi diatas, maka bertujuan untuk mengetahui ketergantungan dapatdijelaskansebagaiberikut: Semakin merek suatu variabel terikat dengan satu atau lebih dikenal, maka tingkat keputusan pembelian

Tabel 7.

Hasil Analisis Regresi Linier Berganda

\begin{tabular}{llllll}
\hline Variabel & \multicolumn{2}{l}{$\begin{array}{l}\text { Unstandardized } \\
\text { Coefficients }\end{array}$} & t & $\begin{array}{l}\text { Standardized } \\
\text { Coefficients } \\
\text { Beta }\end{array}$ & Sig \\
& B & Std.error & & & \\
\hline (constant) & 0.531 & 0.223 & 2.379 & & 0.019 \\
Ekuitas Merek & 0.387 & 0.103 & 3.770 & 0.346 & 0.000 \\
Harga & 0.245 & 0.088 & 2.765 & 0.237 & 0.006 \\
Kualitas Pelayanan & 0.255 & 0.087 & 2.949 & 0.267 & 0.004 \\
Dependen Variabel & $:$ Keputusan Pembelian & & & \\
F Statistik & $: 71.706$ & & & \\
Sig F & $: 0.000$ & & & \\
R $^{2}$ & $: 0.604$ & & & \\
Adjusted R & $: 0.596$ & & & & \\
\hline
\end{tabular}

Sumber: data diolah,2019 
konsumen terhadap merek itu akan semakin tinggi. Semakin sesuai harga yang ditetapkan dengan daya beli konsumen, maka akan $\mathrm{H}_{2}$ semakin meningkatkan keputusan pembelian. Semakin baik kualitas pelayanan yang diberikan maka akan semakin meningkatkan keputusan pembelian.

Hasil uji F yang tertera pada Tabel 7 , menunjukkan nilai signifikansi $\mathrm{F}$ adalah sebesar $0,000(<0,05)$ maka variabel ekuitas merek, harga dan kualitas pelayanan dikatakan layak menjelaskan variabel keputusan pembelian.

Uji hipotesis (uji t) dilakukan untuk menguji signifikansi pengaruh variabel bebas ekuitas merek $\left(\mathrm{X}_{1}\right)$, harga $\left(\mathrm{X}_{2}\right)$ dan kualitas pelayanan $\left(\mathrm{X}_{3}\right)$ secara parsial terhadap variabel terikat keputusan pembelian (Y). Hasil uji hipotesis secara rinci dijelaskan pada Tabel 7. Penjelasan hasil uji hipotesis (Uji t) pada Tabel 7 adalah sebagai berikut.

$\mathrm{H}_{1} \quad$ : Ekuitas merek berpengaruh positif dan signifikan terhadap keputusan pembelian pada gerai Starbucks di Bali.

Variabel ekuitas merek $\left(\mathrm{X}_{1}\right)$ memiliki probabilitas tingkat signifikansi $0,000(<0,05)$. Hasil ini berarti ekuitas merek berpengaruh positif dan signifikan terhadap keputusan pembelian pada gerai Starbucks di Bali, dengan demikian $\mathrm{H}_{1}$ diterima.

$\mathrm{H}_{2}$ : Harga berpengaruh positif dan signifikan terhadap keputusan pembelian pada gerai Starbucks di Bali.

Variabel harga $\left(\mathrm{X}_{2}\right)$ memiliki probabilitas tingkat signifikansi $0,006(<0,05)$. Hasil ini berarti harga berpengaruh positif dan signifikan terhadap keputusan pembelian pada gerai Starbucks di Bali, dengan demikian $\mathrm{H}_{2}$ diterima.

$\mathrm{H}_{3} \quad$ : Kualitas pelayanan berpengaruh positif dan signifikan terhadap keputusan pembelian pada gerai Starbucks di Bali.

Variabel kualitas pelayanan $\left(\mathrm{X}_{3}\right)$ memiliki probabilitas tingkat signifikansi 0,004 $(<0,05)$. Hasil ini berarti kualitas pelayanan berpengaruh positif dan signifikan terhadap keputusan pembelian pada gerai Starbucks di Bali, dengan demikian $\mathrm{H}_{3}$ diterima.

Tabel 7 menunjukkan nilai $\mathrm{R}$ square adalah sebesar 0.604 yang artinya sebesar 60,4 persen variasi keputusan pembelian dipengaruhi oleh ekuitas merek, harga dan kualitas pelayanan, sedangkan sisanya sebesar 39,6 persen dipengaruhi oleh faktor-faktor lain yang tidak dimasukkan ke dalam model penelitian. 
Berdasarkan hasil analisis pengaruh ekuitas merek terhadap keputusan pembelian memiliki probabilitas tingkat signifikansi sebesar 0,000 dengan nilai koefisien beta 0,346. Probabilitas tingkat signifikansi 0,000 (< 0,05) mengindikasikan bahwa variabel ekuitas merek berpengaruh positif terhadap keputusan pembelian. Hasil menunjukkan bahwa, semakin merek Starbucks dikenal oleh konsumen, mempunyai reputasi yang baik sehingga dapat menimbulkan kepercayaan terhadap konsumen dan memiliki kualitas yang sesuai dengan harapan konsumen maka tingkat keputusan pembelian konsumen terhadap Starbucks akan semakin tinggi.

Penelitian ini sesuai dengan yang dilakukan oleh Widhiarta (2015) menyatakan bahwa variabel ekuitas merek memiliki pengaruh positif dan signifikan terhadap keputusan pembelian. Hasil penelitian yang dilakukan oleh Winatapradja(2013) menyatakan ekuitas merek memiliki pengaruh positif dan signifikan terhadap keputusan pembelian. Soebianto (2014) menyatakan bahwa ekuitas merek memiliki pengaruh positif dan signifikan terhadap keputusan pembelian. Penelitian yang dilakukan Sari (2015) menyatakan ekuitas merek memiliki pengaruh positif dan signifikan terhadap keputusan pembelian.

Berdasarkan hasil analisis pengaruh harga terhadap keputusan pembelian memiliki probabilitas tingkat signifikansi sebesar 0,006 dengan nilai koefisien beta 0,237. Probabilitas tingkat signifikansi $0,000 \quad(<$ 0,05) mengindikasikan bahwa variabel harga berpengaruh positif signifikan terhadap keputusan pembelian. Hasil menunjukkan bahwa, semakin sesuai harga yang ditetapkan dengan daya beli konsumen, harga yang ditetapkan sesuai dengan kualitas dan manfaat yang ditawarkan maka tingkat keputusan pembelian konsumen terhadap Starbucks akan semakin tinggi.

Penelitian ini sesuai dengan yang dilakukan oleh Dawood (2015) menyatakan bahwa variabel harga memiliki pengaruh positif dan signifikan terhadap keputusan pembelian. Hasil penelitian yang dilakukan oleh Aswan (2013) menyatakan bahwa harga memiliki pengaruh positif dan signifikan terhadap keputusan pembelian. Penelitian yang dilakukan Hariadi (2013) menyatakan bahwa harga memiliki pengaruh positif dan signifikan terhadap keputusan pembelian. Penelitian yang 
dilakukan Anwar dan Satrio (2015) menyatakan harga berpengaruh positif terhadap keputusan pembelian. Fernando (2018) menyatakan bahwa harga memiliki pengaruh positif dan signifikan terhadap keputusan pembelian.

Berdasarkan hasil analisis pengaruh kualitas pelayanan terhadap keputusan pembelian memiliki probabilitas tingkat signifikansi sebesar 0,004 dengan nilai koefisien beta 0,267 . Probabilitas tingkat signifikansi $0,000 \quad(<0,05)$ mengindikasikan bahwa variabel kualitas pelayanan berpengaruh positif signifikan terhadap keputusan pembelian. Hasil menunjukkan bahwa, semakin mampu Starbucks memberikan pelayanan secara akurat kepada konsumen, mampu menangani keluhan, mampu dalam menumbuhkan kepercayaan konsumen dan mampu berkomunikasi dengan baik kepada konsumen maka tingkat keputusan pembelian konsumen terhadap Starbucks akan semakin tinggi.

Penelitian ini sesuai dengan yang dilakukan oleh Alfredo dan Edward (2015) dalam penelitiannya menyatakan bahwa kualitas pelayanan memiliki pengaruh positif dan signifikan terhadap keputusan pembelian. Denny Aditya (2017) dalam penelitiannya menyatakan bahwa kualitas pelayanan memiliki pengaruh positif terhadap keputusan pembelian. Septiyaningsih (2016) dan Satya (2012) dalam penelitiannya mengemukakan bahwa kualitas pelayanan merupakan variabel yang pengaruhnya paling kuat dan dominan terhadap keputusan pembelian. Penelitian yang dilakukan Khairul Hakim (2017) menyatakan bahwa kualitas pelayanan memiliki pengaruh positif dan signifikan terhadap keputusan pembelian.

Berdasarkan hasil uji $\mathrm{F}$ menunjukkan nilai signifikansi $\mathrm{F}$ adalah sebesar 0,000 (< 0,05) maka variabel ekuitas merek, harga dan kualitas pelayanan dikatakan berpengaruh secara simultan terhadap keputusan pembelian. Nilai R square adalah sebesar 0.604 yang artinya sebesar 60,4 persen variasi keputusan pembelian dipengaruhi oleh ekuitas merek, harga dan kualitas pelayanan, sedangkan sisanya sebesar 39,6 persen dipengaruhi oleh faktorfaktor lain yang tidak dimasukkan ke dalam model penelitian. Hasil ini menujukkan bahwa, semakin merek dikenal, semakin sesuai harga yang ditetapkan dengan daya beli konsumen dan semakin baik kualitas pelayanan yang diberikan maka akan semakin meningkatkan keputusan pembelian. 
Penelitian ini sesuai dengan yang yang ditetapkan dengan daya beli konsumen, dilakukan oleh Widhiarta (2015) menyatakan harga yang ditetapkan sesuai dengan kualitas bahwa variabel ekuitas merekmemiliki pengaruh dan manfaat yang ditawarkan maka akan positif dan signifikan terhadap keputusan semakin meningkatkan keputusan pembelian. pembelian. Dawood (2015) menyatakan bahwa variabel harga memiliki pengaruh positif dan signifikan terhadap keputusan pembelian. Denny Aditya (2017) dalam penelitiannya menyatakan bahwa kualitas pelayanan memiliki pengaruh positif terhadap keputusan pembelian.

Hasil penelitian ini memberikan sebuah implikasi teoritis mengenai bagaimana pentingnya ekuitas merek, harga dan kualitas pelayanan terhadap keputusan pembelian. Hasil yang diperoleh dari penelitian ini menunjukkan hubungan secara langsung antar variabel, seperti hubungan antara variabel ekuitas merek dengan keputusan pembelian. Penelitian ini menunjukkan bahwa, semakin merek Starbucks telah dikenal oleh konsumen, mempunyai reputasi yang baik sehingga dapat menimbulkan kepercayaan terhadap konsumen dan memiliki kualitas yang sesuai dengan harapan konsumen maka tingkat keputusan pembelian konsumen terhadap Starbucks akan semakin tinggi. Hubungan antara variabel harga dengan keputusan pembelian menunjukkan bahwa, semakin sesuai harga Hubungan antara variabel kualitas pelayanan terhadap keputusan pembelian menunjukkan bahwa, semakin mampu Starbucks memberikan pelayanan secara akurat kepada konsumen, mampu menangani keluhan, mampu dalam menumbuhkan kepercayaan konsumen dan mampu berkomunikasi dengan baik kepada konsumen maka akan meningkatkan keputusan pembelian.

Implikasi praktis penelitian ini menekankan pada manfaat untuk meningkatkan keputusan pembelian melalui ekuitas merek, harga dan kualitas pelayanan sehingga dapat meningkatkan keputusan pembelian di Starbucks. Starbucks sudah mencapai tingkat ekuitas merek yang baik, hal terpenting adalah mempertahankan dan meningkatkan kinerja secara keseluruhan mengingat jumlah konsumen loyalnya tergolong tinggi terhadap Starbucks. Starbucks diharapkan dapat mempertahankan kualitas pelayanan terhadap konsumen sehingga dapat meningkatkan penjualan melalui konsumen yang membeli 
kopi.

Beberapa keterbatasan penelitian yang terdapat dalam penelitian ini adalah sebagai berikut : Ruang lingkup penelitian ini hanya di wilayah Kota Denpasar dan Badung dengan jumlah sampel sebanyak 145 orang, sehingga hasil penelitian ini tidak dapat digeneralisir dalam lingkup yang lebih luas.

Penelitian ini hanya meneliti pengaruh variabel ekuitas merek, harga dan kualitas pelayanan terhadap keputusan pembelian, sedangkan masih ada banyak variabel yang mempengaruhi keputusan pembelian seperti gaya hidup, kualitas produk, lokasi dan promosi

\section{SIMPULAN DAN SARAN}

Ekuitas merek berpengaruh positif signifikan terhadap keputusan pembelian. Dapat dikatakan bahwa, semakin merek Starbucks dikenal oleh konsumen, mempunyai reputasi yang baik sehingga dapat menimbulkan kepercayaan terhadap konsumen dan memiliki kualitas yang sesuai dengan harapan konsumen maka tingkat keputusan pembelian konsumen terhadap Starbucks akan semakin tinggi.

Harga berpengaruh positif signifikan terhadap keputusan pembelian. Dapat dikatakan bahwa, semakin sesuai harga yang ditetapkan dengan daya beli konsumen, harga yang ditetapkan sesuai dengan kualitas dan manfaat yang ditawarkan maka akan semakin meningkatkan keputusan pembelian.

Kualitas pelayanan berpengaruh positif signifikan terhadap keputusan pembelian. Dapat dikatakan bahwa, semakin mampu Starbucks memberikan pelayanan secara akurat kepada konsumen, mampu menangani keluhan, mampu dalam menumbuhkan kepercayaan konsumen dan mampu berkomunikasi dengan baik kepada konsumen maka akan meningkatkan keputusan pembelian.

Berdasarkan simpulan yang didapat saran-saran yang dapat diberikan adalah sebagai berikut : Starbucks sudah mencapai tingkat ekuitas merek yang baik, hal terpenting adalah mempertahankan dan meningkatkan kinerja secara keseluruhan mengingat jumlah konsumen loyalnya tergolong tinggi terhadap Starbucks. Starbucks diharapkan dapat mempertahankan kualitas pelayanan terhadap konsumen sehingga dapat meningkatkan penjualan. Bagi peneliti selanjutnya diharapkan agar dapat mengkaji ulang penelitian ini dengan menggunakan variabel-variabel lain yang berpengaruh 
terhadap keputusan pembelian seperti variabel gaya hidup, kualitas produk, lokasi, promosi.

\section{REFERENSI}

Aaker, David A. 2013. Manajemen Pemasaran Strategis. Edisi 8. Jakarta : Salemba

Amrullah, Artika Romal dan Sasi Agustin. 2016. Pengaruh Kualitas Produk, Harga dan Citra Merek Terhadap Keputusan Pembelian Honda Beat. Jurnal Ilmu dan Riset Manajemen, Vol. 5, No. 7, pp 1-15. Aristyani, Ida Ayu Raras dan Kerti Yasa, Ni Nyoman. 2013. Perbandingan Brand Equity Produk Shampo Merek Sunsilk Dengan Merek Pantene. Jurnal Manajemen dan Kewirausahaan, 15(2) Hal. 179-190.

Armandhani, Herdian dan Sukaatmadja, I Putu Gede. 2014. Analisis Perbandingan Brand Equity Produk Obat Anti Nyamuk Oles Merek Autan Dengan Merek Soffel Di Kota Denpasar. E-Journal Manajemen Universitas Udayana, 3(1) Hal. 149-168.

Aswan, Hidayat. 2013. Analisis Pengaruh Kualitas Produk, Promosi dan Persepsi Harga Terhadap Minat Beli Ulang Pelanggan Voucher Isi Ulang XL di Universitas Semarang. Jurnal Fakultas Ekonomi Universitas Semarang. 2(5): 59-78.

Chen, Hui-Chu., Trans World University, Green, Robert D., Lynn University. 2012. Brand Equity, Marketing Strategy And Consumer Income: A Hypermarket Study. International Business \& Economics Research Journal, 11(2) Hal.1-18.

Chen, Tser-Yieth., Yeh, Tsai-Lien., and Jheng Wun-Sin. 2013. Factor Influencing Brand Association. African Journal of Business Management, 7(19) Hal.19141926.

Dawood, D., Khan. 2015. Impact of Marketing Mix On Consumer Buying Behavour In Organic Product Bharathiar University. International Journal of Research of Finance and Marketing, 6(10): 43-54
Durianto, Darmadi dkk. 2011. Strategi Menaklukkan Pasar Melalui Riset Ekuitas dan Perilaku Merek. Jakarta: PT. Gramedia Pustaka Utama.Empat.

Fernando, Made Fajar. 2018. Pengaruh Kualitas Produk, Harga, Promosi dan Distribusi Terhadap Keputusan Pembelian Produk Sanitary Ware Toto Di Kota Denpasar. E-Jurnal Manajemen Unud, Vol.7, No. 1 : 441-469.

Garlina, Yossy Hanna. 2014. Comparison of Skin Moisturizer: Consumer-Based Brand Equity (CBBE) Factors In Clusters Based On Consumer Ethnocentrism. Journal The Winners, 15(2) Hal. 115-122.

Ghanimata, F., dan Kamal, M. 2012. Analisis Pengaruh Harga, Kualitas Produk dan Lokasi Terhadap Keputusan Pembelian (Studi Pada Pembeli Produk Bandeng Juwana Elrina Semarang). Diponegoro Journal Of Management, 1(2), Hal 1-10

Gunawan, Adisapitro. 2012. Manajemen Pemasaran Edisi Pertama Jilid 2. Yogyakarta: Sekolah Tinggi Ilmu Manajemen YKPN.

Humdiana. 2005. Strategi Pemasaran. Jakarta: PT Gramedia Pustaka Mizan Pustaka.

Kotler, Philip \& Armstrong, Gary. 2012. Prinsip-Prinsip Pemasaran Edisi 13 Jilid Satu. Jakarta: Erlangga

Lupiyoadi, Rambat. 2013. Manajemen Pemasaran Jasa Edisi 13. Salemba Empat Jakarta.

Omer, Kursad Tufekci. 2014. Audience-Based Brand Equity: A Research on Women's Tennis Association Championships Istanbul 2013. International Business Research, 7(9) Hal. 141-156.

Sari, Novita. 2015. Pengaruh Ekuitas Terhadap Keputusan Pembelian Smartphone Samsung Galaxy (Studi Kasus Pada Mahasiswa Program Diploma III Fakultas Ekonomi dan Bisnis Universitas Jambi). Jurnal Manajemen Fakultas Ekonomi dan Bisnis Universitas Jambi. Vol 17 No. 2 Hal. 53-71. 
Satit RP, Tat HH, Rasli A, Chin TA, Sukati I. 2012. The Relationship Between Marketing Mix And Costumer Decision-Making Over Travel Agents: An Empirical Study. International Journal of Academic Research in Business and Social Scienes. Vol. 2, No. 6, pp 522-530.

Schiffman, Leon G \& Kanuk, Leislie Lazar. 2008. Consumer Behavior Seventh Edition. USA: Prentice-Hall, Inc.

Septiyaningsih, Putu Mutia., G.P. Ganda Putra., Luh Putu Wrasiati. 2016. Analisis Faktor-Faktor Yang Mempengaruhi Keputusan Pembelian Produk Roti "Bapak Bakery”. Jurnal Rekayasa dan Manajemen Agroindustri Unud, 4(3) pp: 23-35.

Shabbir, Chatchai Pitsaphol Rizwan \& Zhang Jing. 2014. The Relationship of Brand Equity Dimensions: A Case Study of Samsung Brand in Thailand. European Journal of Business and Management, 6(1) Hal. 182-189.

Shahin, Arash., Ali Kazemi., Hamseh Kazemi Mahyari. 2012. How Consumer's Perception of Country of Origin Affects Brand Equity: A Case Study in Iran Middle-East. Journal of Scientific Research, 12(6) Hal. 8-10.

Shimp, T. A. 2014. Komunikasi Pemasaran Terpadu dalam Periklanan dan Promosi. Jakarta: Salemba Empat.

Sigiro, Afriani Cristine., Putri, Yuliani Rachma., Imran, Ayub Ilfandy. 2016. Analisis Faktor Pembentuk Ekuitas Merek Toyota dan Daihatsu di Indonesia. Jurnal Sosioteknologi, 15(3) Hal. 335-345.

Silaban, Bernard E., dan Marselia, Fitri Andini. 2016. Perbandingan Ekuitas Merek Sepatu Olahraga Nike dan Adidas. Jurnal Esensi, 19(2) Hal. 84-111.

Sipayung, Mei Linda dan Asmina Herawaty Sinaga. 2017. Marketing Mix Effect 